\title{
Effects of beet western yellows virus on growth and yield of oilseed rape (Brassica napus)
}

\author{
C. N. JAY*, S. ROSSALL AND H. G. SMITH \\ IACR-Broom's Barn, Higham, Bury St Edmunds, Suffolk IP28 6NP, UK \\ University of Nottingham Sutton Bonington Campus, Loughborough, Leicestershire LE12 5RD, UK
}

(Revised MS received 15 March 1999)

\begin{abstract}
SUMMARY
Field trials were undertaken in Suffolk in commercial crops of autumn-sown oilseed rape cv. Capricorn during 1993/94, cv. Apex in 1994/95. Plots were artificially infected with beet western yellows virus (BWYV) using viruliferous Myzus persicae, giving 73 to $94 \%$ infection. Control plots had natural infection ranging from 0 to $17 \cdot 8 \%$. Destructive plant samples were taken from each of the infected and control plots throughout the seasons for growth analyses, and final yields were measured on $44 \mathrm{~m}^{2}$ areas combine harvested from each plot. The seed yields of infected plots were 26 and $11 \%$ lower than control plots in 1994 and 1995 respectively $(P<0 \cdot 001)$.

Harvested seed yields were shown to be inversely proportional to the area of the plot that was inoculated with BWYV. Infection significantly lowered the oil content in 1995 from $47 \cdot 9$ to $46 \cdot 8 \%$ $(P<0 \cdot 001)$, and increased glucosinolate levels from $16 \cdot 12$ to $18.37 \mu \mathrm{mol} / \mathrm{g}(P<0 \cdot 01)$. BWYV caused a significant reduction in plant height and in numbers of primary branches in the 1993/94 trial and had an effect on the dry weight of the leaves, stalks, racemes and pods at some sample dates in both seasons. Virus-testing of infected plants showed that BWYV was present in the pod wall, the septum and seed coat; two of 78 embryo samples also contained virus. It was concluded that BWYV can cause significant yield losses in those years in which there is a high incidence of virus in the overwintered crops.
\end{abstract}

\section{INTRODUCTION}

Approximately 400000 ha of autumn-sown oilseed rape (Brassica napus L.) are grown each year in the UK as a source of vegetable oil. The time at which the seedlings emerge coincides with the autumn migration of the peach-potato aphid, Myzus persicae, which colonizes, and overwinters on oilseed rape (Smith \& Hinckes 1984). Beet western yellows virus (BWYV genus Luteovirus) is phloem-specific and is transmitted in a persistent manner by $M$. persicae. The virus is introduced into the oilseed rape crop by incoming aphids in the autumn, and a high percentage of infected plants have been found within crops both in the UK (Smith \& Hinckes 1985) and in other parts of Europe (Schröder 1994; Maissoneuve et al. 1995) in some years. In the UK, the natural incidence of

* To whom all correspondence should be addressed, at Horticulture Research International, East Malling, West Malling, Kent ME19 6BJ, UK.

Email: Chantelle.Jay@hri.ac.uk infection within a crop can range from as low as 4 up to $86 \%$ (Lane \& Walters 1993; Hardwick et al. 1994). Despite the potential risk of yield loss as a result of BWYV infection, little is known about the effect of the virus on the crop. Previous studies of the effects of the virus on yield have relied on natural infection of the crop, with control plots being sprayed with aphicides through the autumn to limit infection. Smith and Hinckes (1984) compared the yields of heavily infected plots with those of lightly infected plots and found a decrease of $13 \%$ due to the effect on oil and seed yields. Further trials by Hill et al. (1989) proved inconclusive as only four out of 19 trials showed a significant yield decrease. These latter trials were carried out in years with a low incidence of natural infection. More recent work (Schröder 1994) showed yield decreases of 40 and $50 \%$ for two out of the three oilseed rape cultivars tested, when individual plants in small experimental plots were infected with BWYV. This paper describes field trials to study the effects of BWYV on the growth and yield of winter oilseed rape, using artificial inoculation to control the infection. 


\section{MATERIALS AND METHODS}

Field trials were undertaken in commercial crops of autumn-sown oilseed rape at Wickhambrook, Suffolk during 1993/94, and 1994/95. In each season, a trial was conducted to study the effect of BWYV on the growth and yield of the crop, by taking destructive samples on subplots throughout the season for growth analyses, and by mechanically harvesting the main plots to determine the final yield. In the second season an additional trial was carried out to examine the effect of inoculation pressure on final yield.

\section{Experimental design and treatments}

In the first season a growth analysis trial was carried out on a crop of winter oilseed rape cv. Capricorn, drilled on 17 August 1993, and in the second season on a crop of cv. Apex drilled on 3 September 1994, both at a seed rate of $7 \mathrm{~kg} / \mathrm{ha}$. The selection of the variety was at the discretion of the grower. Both trials consisted of four blocks each comprised of four main plots, $6 \times 22 \mathrm{~m}$, to give 16 plots in total. Two main plots in each block (eight plots in total) were inoculated with BWYV in early October, when the plants were at the 5-6 leaf stage in 1993, and the 2-3 leaf stage in 1994. Each main $6 \times 22 \mathrm{~m}$ plot was divided into $3 \times 22 \mathrm{~m}$ strips. One strip was marked into $1 \mathrm{~m}^{2}$ subplots (with a $1 \mathrm{~m}$ guard between the subplots) which were destructively sampled throughout the season; the order of sampling these subplots was randomized. The second strip was combineharvested to give final yield. To facilitate access into the plots after stem extension, the herbicide glyphosate was applied to the edges of the main plots in April.

\section{Inoculation with $B W Y V$}

Inoculations were made using viruliferous $M$. persicae which had been raised on BWYV-infected oilseed rape plants in a glasshouse. Leaf pieces of these plants plus aphids were distributed among all plants in the field plots in October and left for up to 2 weeks, depending on the weather conditions. During this time the glasshouse-grown leaves wilted, and the viruliferous aphids moved onto and infected the young oilseed rape plants.

\section{Aphid control}

The 1993/94 trial was sprayed with pirimicarb (Aphox: Zeneca) at $140 \mathrm{~g} /$ ha to kill the aphids used to inoculate the plots; three further applications of insecticide (one of lambda-cyhalothrin [Hallmark: Zeneca] at $150 \mathrm{ml} / \mathrm{ha}$ and two of pirimicarb at 280 $\mathrm{g} / \mathrm{ha}$ ) were made during October and November to control incoming aphids. The 1994/95 trial was initially sprayed with lambda-cyhalothrin at 150 $\mathrm{ml} /$ ha with an additional application of pirimicarb at $140 \mathrm{~g} / \mathrm{ha}$.

\section{Cultural practice}

The trial areas received the grower's usual applications of fungicide and herbicide, but not insecticide. The insecticide cypermethrin (Ambush C: Zeneca) was applied to the surrounding areas at a rate of $250 \mathrm{ml} / \mathrm{ha}$.

$$
\text { Growth analyses }
$$

\section{Destructive harvests}

One subplot $\left(1 \mathrm{~m}^{2}\right)$ was harvested from each main plot at eight growth stages (Table 1), giving eight samples from infected plots and eight from uninoculated control plots on each sampling occasion. All plants within these $1 \mathrm{~m}^{2}$ quadrats were harvested by cutting at the base of the plant; the plants were

Table 1. Growth stage and date of sampling for growth analyses and mean incidence of BWYV infection in inoculated and control plots, 1993/94, 1994/95

\begin{tabular}{|c|c|c|c|c|c|c|}
\hline \multirow[b]{3}{*}{ Growth stage* } & \multirow{3}{*}{$\begin{array}{c}\text { Trial } 1 \\
\\
\text { Date } \\
\text { sampled }\end{array}$} & \multicolumn{2}{|c|}{$1993 / 1994$} & \multirow{3}{*}{$\begin{array}{c}\text { Trial } 2 \\
\\
\text { Date } \\
\text { sampled }\end{array}$} & \multicolumn{2}{|c|}{$1994 / 1995$} \\
\hline & & \multicolumn{2}{|c|}{$\%$ of BWYV in plots ${ }^{+}$} & & \multicolumn{2}{|c|}{$\%$ BWYV in plots } \\
\hline & & Inoculated & Control & & Inoculated & Control \\
\hline $1,7-1,8(7-8$ true leaves $)$ & $8 \mathrm{Nov}$ & $15 \cdot 0$ & $3 \cdot 1$ & - & & \\
\hline $1,9-1,10(9-10$ true leaves $)$ & $7 \mathrm{Dec}$ & $73 \cdot 1$ & $5 \cdot 0$ & $14 \mathrm{Dec}$ & $90 \cdot 0$ & 0 \\
\hline 2,0 (rosette form) & 8 Feb & $94 \cdot 3$ & $17 \cdot 8$ & 16 Feb & $88 \cdot 7$ & $0 \cdot 6$ \\
\hline 3,3 (green bud) & $31 \mathrm{Mar}$ & $91 \cdot 2$ & $9 \cdot 3$ & $3 \mathrm{Apr}$ & $86 \cdot 0$ & $1 \cdot 0$ \\
\hline 4,5 (50\% flowering) & 27 Apr & $96 \cdot 2$ & $11 \cdot 8$ & $24 \mathrm{Apr}$ & $88 \cdot 7$ & $1 \cdot 2$ \\
\hline 5,5 (early pod development) & 23 May & $91 \cdot 8$ & $10 \cdot 6$ & 24 May & $89 \cdot 4$ & $1 \cdot 2$ \\
\hline 6,3 (green seeds in pod) & 20 Jun & $89 \cdot 4$ & $6 \cdot 2$ & 22 Jun & - & - \\
\hline 6,9 (before final harvest) & $20 \mathrm{Jul}$ & - & - & $20 \mathrm{Jul}$ & - & - \\
\hline
\end{tabular}

* From Sylvester-Bradley \& Makepeace (1984).

+ Mean for eight plots.

- Not sampled. 

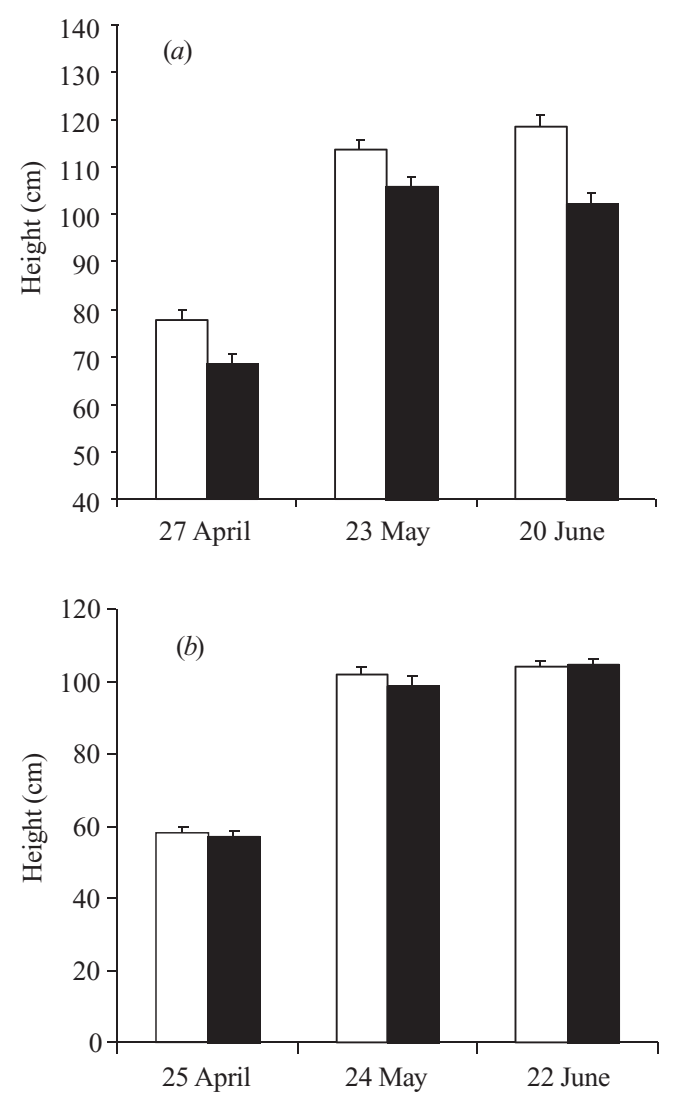

Fig. 1. The effect of BWYV on the height of oilseed rape in (a) 1994 and (b) 1995. Vertical bars represent the standard error of the means with 11 D.F.

counted, and fresh weights of the whole sample, and fresh and dry weights $\left(72 \mathrm{~h}\right.$ at $\left.80^{\circ} \mathrm{C}\right)$ of a subsample of 20 plants were measured. Detailed growth analyses of the sampled plants included measurements of leaf area, dry weights of the leaves, stalks, flowers, pods and branches, and numbers of branches, pods and seeds. The heights of 20 plants from each subplot were measured in the April, May and June samples. In July of each season, before final harvest, subsamples of five plants in 1994 and 10 in 1995 were taken for pod measurements. In 1994, counts were made of the total number of pods produced by each of these five plants; the numbers of seeds per pod were counted for 10 pods from each plant, selected at regular height intervals up the raceme. In the 1995 season 10 plants were sampled and the pod numbers on the branches and racemes were counted. These pods were then hand threshed for the branch and raceme components separately to obtain seed numbers and the 1000-seed weight (TSW).

The remainder of the $1 \mathrm{~m}^{2}$ sample was threshed and winnowed to obtain the seed yield. The TSW was measured for each of the 16 plots in both seasons and in 1994 the seed samples were also size graded using a series of sieves.

All growth analyses data were analysed using the Genstat statistical package for analysis of variance (Payne et al. 1987) with 11 degrees of freedom. The 1994 data for the seed number per pod were analysed separately for each height category.

\section{Final yield}

The final harvests were made on 4 August 1994 and 28 July 1995 using a SAMPO Rosenlew 2010 combine harvester with a $2 \mathrm{~m}$ swath to give a total harvested area of $44 \mathrm{~m}^{2}$ per plot. The total seed yield per plot was weighed using a weighing bucket inside the seed tank. Moisture and oil content of $20 \mathrm{~g}$ seed samples from each plot were assessed by ADAS Laboratory Services, Wolverhampton, using the nuclear magnetic resonance (NMR) method (Tomassetti et al. 1991), and seed yield adjusted to $91 \%$ dry matter. Glucosinolate levels were also measured in the 1995 season using the X-ray fluorescence method with $10 \mathrm{~g}$ of milled sample (Schnug \& Haneklaus 1988). All data were analysed using analysis of variance with 11 degrees of freedom.

\section{$B W Y V$ infection}

During the sequential harvests, the oldest nonsenescent leaves from 20 plants per plot were checked for BWYV using an indirect ELISA protocol, based on that described by D'Arcy et al. (1989), to determine the proportion of infected plants per plot (Table 1). If the leaves had dropped, the pods were tested for BWYV. Twenty samples from the strips to be combine harvested were also tested for virus on 11 March 1994 and 4 April 1995, for the 1993/94 and 1994/95 seasons, respectively.

\section{Virus content of pod and seed components}

In June 1994, two pods from each of 78 BWYVinfected plants were dissected and separated into pod walls, septa, seed coats and embryos. For one sample the seed coat was also separated into the outer and inner coat. The pod components were tested for BWYV using ELISA (Clark \& Adams 1977).

\section{Effect of different inoculum levels on seed yield, 1994/95}

A trial was set up in a commercial crop of winter rape drilled on 4 September 1994 with the cv. Capricorn at a seed rate of $8 \mathrm{~kg} / \mathrm{ha}$, and consisted of four blocks, each containing six plots $24 \mathrm{~m}$ long and $3 \mathrm{~m}$ wide. The treatments within the blocks were randomized. Two plots in each block were left uninoculated; two were inoculated as described previously, and two received a reduced intensity of inoculation, achieved by applying infected aphids to alternate strips $2 \mathrm{~m}$ long 
and $2 \mathrm{~m}$ apart. Prior to inoculation, ten plants per plot were checked for aphids and tested for virus. Plots were inoculated on 19 October 1994 when the oilseed rape plants were at the 2-3 leaf stage. The plots were subsequently sprayed with pirimicarb at a rate of $140 \mathrm{~g} / \mathrm{ha}$ on 2 and 29 November. As with the previous trials the plots received the farmer's usual spray programme, apart from insecticides; the insecticide cypermethrin was applied to the surrounding area. In April 1995, 54 plants per plot were tested for the presence of BWYV. The trial was harvested on 28 July 1995. Yield data were analysed using analysis of variance with 18 degrees of freedom.

\section{RESULTS}

\section{$B W Y V$ infection}

The virus incidence in the sequentially harvested plots averaged $89 \%$ in both 1994 and 1995 for the inoculated plots, while the virus incidence in the control plots averaged $10 \%$ in 1994 and $1 \%$ in 1995 (the incidence of virus in November 1993 was not included in the mean value as it was unrepresentative) (Table 1). The virus incidence in the harvested plots had a mean value of $92.5 \%$ in 1994 and $80 \%$ in 1995 for the inoculated plots, with an incidence of $3.1 \%$ in 1994 and zero infection in 1995 for the control plots.

\section{Growth analyses}

The height of BWYV-infected plants was significantly lower than that of control plants in 1994. In April, infected plants had an average height of $68.5 \mathrm{~cm}$ (12\% less than controls) $(P<0 \cdot 01, \mathrm{LSD}=6 \cdot 25,11$ D.F. $)$, in May $105.9 \mathrm{~cm}(7 \%$ less $)(P<0.05$, LSD $=$ $6.77,11$ D.F. $)$ and in June $102 \cdot 2 \mathrm{~cm}(14 \%$ less $)(P<$ $0 \cdot 001, \mathrm{LSD}=7 \cdot 28,11$ D.F.) (Fig. $1 a$ ). However, there was no clear effect of BWYV on height in 1995 (Fig. $1 b)$. BWYV-infected plants had significantly less leaf area per plant $(P<0.05)$ and lower dry weights for both the leaves $(P<0.05)$ and stalks $(P<0.01)$ in March 1994. There was also a decrease in stem plus raceme weight $(P<0 \cdot 01)$ and main raceme pod weight $(P<0 \cdot 001)$ in June 1994 (Table 2). In 1995, infection

Table 2. The dry weight ( $g$ ) of leaf, stalk and pod components and leaf area $\left(\mathrm{cm}^{2}\right)$ of the sub-sampled plants with and without BWYV,1993/94 and 1994/95 (data are per plant)

\begin{tabular}{|c|c|c|c|c|c|c|c|}
\hline & \multirow{2}{*}{$\begin{array}{l}\text { Dry weight of } \\
\text { components, leaf } \\
\text { area }\end{array}$} & \multicolumn{3}{|c|}{$1993 / 94$} & \multicolumn{3}{|c|}{$1994 / 95$} \\
\hline & & Uninfected & $\begin{array}{l}\text { BWYV- } \\
\text { infected }\end{array}$ & $\begin{array}{l}\text { S.E. } \\
11 \text { D.F. }\end{array}$ & Uninfected & $\begin{array}{l}\text { BWYV- } \\
\text { infected }\end{array}$ & $\begin{array}{l}\text { S.E. } \\
11 \text { D.F. }\end{array}$ \\
\hline Nov & Leaf area & $137 \cdot 0$ & $124 \cdot 4$ & $10 \cdot 49$ & - & - & - \\
\hline \multirow[t]{3}{*}{ Dec } & Leaf & - & - & - & $0 \cdot 51$ & 0.53 & $0 \cdot 066$ \\
\hline & Stalk & - & - & - & $0 \cdot 35$ & $0 \cdot 33$ & $0 \cdot 032$ \\
\hline & Leaf area & $117 \cdot 3$ & $114 \cdot 0$ & $8 \cdot 40$ & - & - & - \\
\hline \multirow{3}{*}{$\mathrm{Feb}$} & Leaf & 1.08 & $1 \cdot 01$ & $0 \cdot 091$ & $0 \cdot 64$ & $0 \cdot 62$ & $0 \cdot 054$ \\
\hline & Stalk & $0 \cdot 50$ & $0 \cdot 51$ & $0 \cdot 039$ & $0 \cdot 45$ & $0 \cdot 44$ & 0.025 \\
\hline & Leaf area & $125 \cdot 0$ & $117 \cdot 0$ & $9 \cdot 04$ & - & - & - \\
\hline \multirow[t]{3}{*}{ Mar } & Leaf & $2 \cdot 03$ & $1 \cdot 78$ & $0 \cdot 094$ & $0 \cdot 94$ & $0 \cdot 85$ & $0 \cdot 098$ \\
\hline & Stalk & 1.60 & $1 \cdot 29$ & 0.734 & $0 \cdot 82$ & $0 \cdot 66$ & $0 \cdot 077$ \\
\hline & Leaf area & $346 \cdot 7$ & $298 \cdot 6$ & $16 \cdot 06$ & - & - & - \\
\hline \multirow[t]{4}{*}{ Apr } & Leaf & $2 \cdot 36$ & $2 \cdot 63$ & $0 \cdot 246$ & $1 \cdot 17$ & $1 \cdot 26$ & $0 \cdot 162$ \\
\hline & Stalk & $5 \cdot 14$ & $4 \cdot 54$ & $0 \cdot 494$ & $2 \cdot 50$ & $2 \cdot 34$ & $0 \cdot 307$ \\
\hline & Flower heads & - & - & - & $0 \cdot 31$ & $0 \cdot 28$ & 0.031 \\
\hline & Leaf area & $465 \cdot 0$ & $446 \cdot 0$ & $47 \cdot 60$ & - & - & - \\
\hline \multirow[t]{5}{*}{ May } & Leaf & $1 \cdot 07$ & $1 \cdot 39$ & $0 \cdot 198$ & $0 \cdot 91$ & $1 \cdot 02$ & $0 \cdot 131$ \\
\hline & Stem and raceme & 4.99 & $5 \cdot 03$ & $0 \cdot 567$ & $3 \cdot 58$ & $3 \cdot 20$ & $0 \cdot 349$ \\
\hline & Pods on raceme & $1 \cdot 35$ & $1 \cdot 28$ & $0 \cdot 121$ & 1.05 & $0 \cdot 66$ & $0 \cdot 060$ \\
\hline & $\begin{array}{l}\text { Primary branches and } \\
\text { pods }\end{array}$ & 1.75 & 1.78 & $0 \cdot 440$ & $1 \cdot 29$ & 1.02 & $0 \cdot 219$ \\
\hline & Leaf area & $210 \cdot 0$ & $238 \cdot 0$ & $31 \cdot 40$ & - & - & - \\
\hline \multirow[t]{6}{*}{ Jun } & Leaf & $0 \cdot 50$ & $0 \cdot 54$ & $0 \cdot 076$ & $0 \cdot 39$ & $0 \cdot 51$ & 0.037 \\
\hline & Stem and raceme & $6 \cdot 24$ & $4 \cdot 70$ & $0 \cdot 370$ & $3 \cdot 42$ & $3 \cdot 74$ & $0 \cdot 235$ \\
\hline & Pods on raceme & $5 \cdot 00$ & $4 \cdot 00$ & $0 \cdot 194$ & $3 \cdot 34$ & $2 \cdot 93$ & $0 \cdot 137$ \\
\hline & Primary branches & 1.79 & $1 \cdot 39$ & $0 \cdot 263$ & $0 \cdot 88$ & 1.08 & $0 \cdot 118$ \\
\hline & $\begin{array}{l}\text { Pods on Primary } \\
\text { branches }\end{array}$ & $3 \cdot 44$ & $2 \cdot 70$ & $0 \cdot 556$ & $1 \cdot 74$ & $2 \cdot 35$ & $0 \cdot 295$ \\
\hline & $\begin{array}{l}\text { Secondary branches and } \\
\text { pods }\end{array}$ & $0 \cdot 06$ & $0 \cdot 01$ & $0 \cdot 033$ & $0 \cdot 09$ & $0 \cdot 03$ & 0.051 \\
\hline
\end{tabular}


Table 3. Effect of BWYV on numbers of primary branches, pods, seeds per pod and 1000 seed weight (TSW) of oilseed rape, 1994 and 1995

\begin{tabular}{|c|c|c|c|c|}
\hline Yield component & Month & Uninfected & BWYV-infected & S.E. $(11$ D.F. $)$ \\
\hline \multirow[t]{3}{*}{ Primary branches } & Jun $1994(10)^{*}$ & $4 \cdot 76$ & $4 \cdot 06$ & $0 \cdot 253$ \\
\hline & Jun 1995 (10) & 3.78 & 3.65 & $0 \cdot 233$ \\
\hline & Jul 1995 (10) & $4 \cdot 42$ & $4 \cdot 65$ & $0 \cdot 410$ \\
\hline \multirow[t]{3}{*}{ Pods on main raceme } & Jun 1994 (10) & $46 \cdot 7$ & $48 \cdot 5$ & $1 \cdot 64$ \\
\hline & Jul 1994 & $53 \cdot 3$ & $50 \cdot 8$ & $2 \cdot 68$ \\
\hline & Jul 1995 (10) & $43 \cdot 6$ & $41 \cdot 4$ & 1.73 \\
\hline \multirow[t]{2}{*}{ Aborted pods on raceme } & Jun 1994 (10) & $6 \cdot 36$ & $4 \cdot 11$ & $0 \cdot 480$ \\
\hline & Jul 1995 (10) & $10 \cdot 31$ & $11 \cdot 10$ & 0.685 \\
\hline \multirow[t]{2}{*}{ Pods on branches } & Jun 1994 (10) & $47 \cdot 4$ & $46 \cdot 3$ & $7 \cdot 90$ \\
\hline & Jul 1995 (10) & $45 \cdot 8$ & $58 \cdot 1$ & $10 \cdot 94$ \\
\hline \multirow[t]{2}{*}{ Seeds per raceme pod } & $\begin{array}{l}\text { Jul } 1994(5,10 \\
\text { pods/plant })\end{array}$ & $14 \cdot 1$ & $8 \cdot 4$ & $0 \cdot 88$ \\
\hline & Jul 1995 (10) & $15 \cdot 1$ & $11 \cdot 4$ & $0 \cdot 77$ \\
\hline Seeds per branch pod & Jul 1995 (10) & $13 \cdot 7$ & $8 \cdot 2$ & $0 \cdot 77$ \\
\hline \multirow{2}{*}{ TSW of $\mathrm{m}^{2}$ sample $(\mathrm{g})$} & Jul 1994 & $6 \cdot 24$ & $6 \cdot 99$ & $0 \cdot 135$ \\
\hline & Jul 1995 & $5 \cdot 03$ & $5 \cdot 67$ & $0 \cdot 145$ \\
\hline $\begin{array}{l}\text { TSW of seeds from raceme } \\
\text { pods }(\mathrm{g})\end{array}$ & Jul 1995 (10) & $4 \cdot 94$ & $5 \cdot 47$ & $2 \cdot 420$ \\
\hline $\begin{array}{l}\text { TSW of seeds from branch } \\
\text { pods }(\mathrm{g})\end{array}$ & Jul 1995 (10) & $4 \cdot 85$ & $5 \cdot 54$ & $0 \cdot 184$ \\
\hline
\end{tabular}

* Numbers of plants sampled shown in parentheses.

caused lower pod weight in both May $(P<0.001)$ and June $(P<0.05)$, and leaf dry weight in June $(P<$ $0 \cdot 01)$. There was no effect on leaf area, or on dry weights at any other sample dates. BWYV-infection was associated with significantly fewer numbers of primary branches in $1994(P<0 \cdot 05)$, although this effect was not seen in 1995 (Table 3).

\section{Numbers of pods and seeds per pod}

Infection had no significant effect on the numbers of pods produced on the main raceme or on the branches. There were significantly fewer aborted pods $(P<$ 0.001) in June 1994 on the infected plants, however this effect was not seen in 1995. The BWYV-infected plants produced fewer seed per pod (Table 3) but these seed were heavier than those produced by uninfected plants, and therefore they gave a significantly higher TSW $(P<0 \cdot 001)$. Seed size data also showed that the infected plants had larger size seeds which were more closely centred on the mean, i.e. the spread between the size categories was smaller. In the 1995 trial the TSW was higher by $10 \cdot 5$ and $14 \%$ on the raceme and branches of the infected plots respectively. The higher TSW on the branches correlates with the greater decrease in seed numbers per pod. The threshed metre squared sample was a mixture of racemes and branches, and the TSW of the infected seeds was $12.7 \%$ more than the control seeds $(P<0.001)$, in between the values for the raceme or branches alone. However, because there were fewer seeds per pod, this resulted in an overall reduction in seed yield. In 1994 the lower numbers of seed were apparent at all pod positions on the raceme, although the difference was most noticeable at the lower positions (Fig. 2).

\section{$B W Y V$ in pod components}

Virus testing of the components showed that BWYV was present in the pod wall, the septum and the seed coat (Table 4): two of 78 embryo samples gave absorbance values in ELISA of 0.22 and 0.24 , indicating the presence of virus. One seed coat that was dissected into the inner and outer coat showed ELISA absorbance readings of 0.22 for the outer coat indicating the presence of virus, but only 0.07 for the inner coat.

\section{Final seed yields}

Seed yields of 4.14 and $3.04 \mathrm{t} /$ ha were obtained at final harvest in 1994 for control and inoculated plots respectively, with $26 \%$ less yield as a result of BWYV infection $(P<0 \cdot 001, \mathrm{LSD}=0 \cdot 1,11$ D.F. $)($ Fig. $3 a)$. In 1995 , control and inoculated plots gave mean yields of 4.78 and $4.26 \mathrm{t} /$ ha respectively, a significant difference of $11 \%(P<0.001, \mathrm{LSD}=0.09,11$ D.F. $)$ (Fig. $3 b$ ).

There was no significant effect of virus infection on oil content of the samples in 1994, the mean contents being 45.97 and $45.99 \%$ for the control and inoculated plots respectively (s.E. $=0.496,11$ D.F.). However, in 1995, the oil content was $47.91 \%$ in the control plots compared with $46 \cdot 81 \%$ in the BWYV-infected plots, 


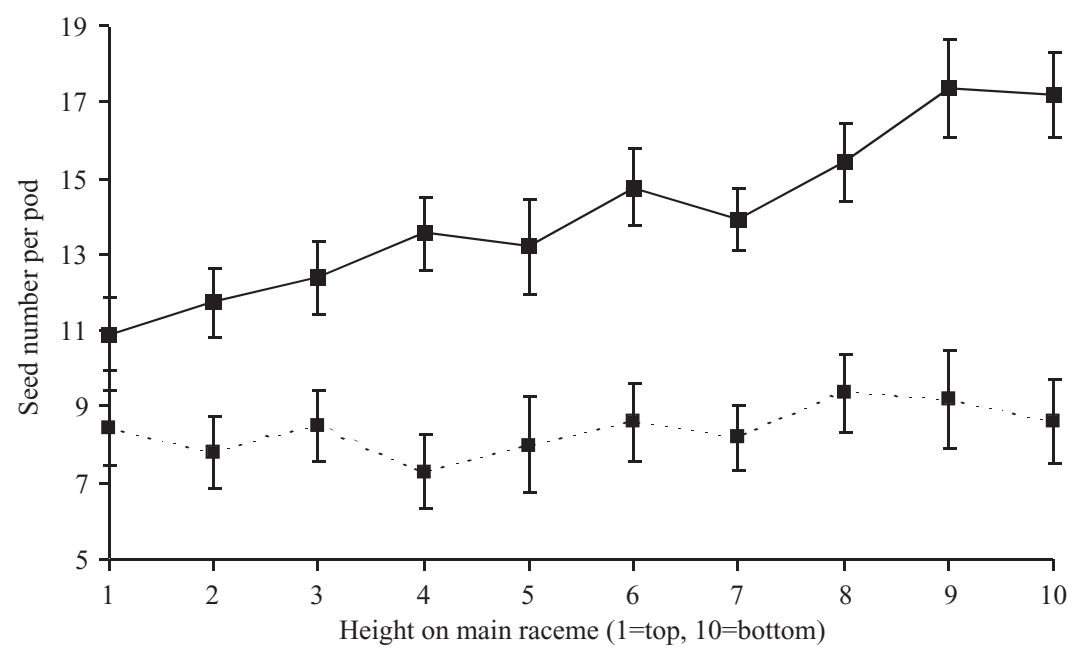

Fig. 2. The effect of BWYV on the number of seeds per pod at differing height on the main raceme, unbroken lines $=$ control, broken lines $=$ infected. Vertical bars represent the standard error of the means with 11 D.F.

Table 4. Detection of $B W Y V$ in oilseed rape pod components

\begin{tabular}{lcc}
\hline \hline & $\begin{array}{c}\text { Number of samples } \\
\text { positive for } \\
\text { BWYV }\end{array}$ & $\begin{array}{c}A_{405} \text { value } \\
\text { mean } \pm \text { SD }\end{array}$ \\
\hline Pod component & $59 / 59$ & $1 \cdot 27 \pm 0 \cdot 451$ \\
Pod wall + septa & $19 / 19$ & $1 \cdot 32 \pm 0 \cdot 407$ \\
Pod wall & $19 / 19$ & $1 \cdot 14 \pm 0 \cdot 491$ \\
Septa & $77 / 78$ & $0 \cdot 79 \pm 0 \cdot 342$ \\
Eeed coat & $2 / 78$ & $0 \cdot 09 \pm 0 \cdot 032$ \\
\hline \hline
\end{tabular}

Mean $A_{405}$ readings \pm S.D. for uninfected controls $=$ $0 \cdot 072 \pm 0 \cdot 014$.

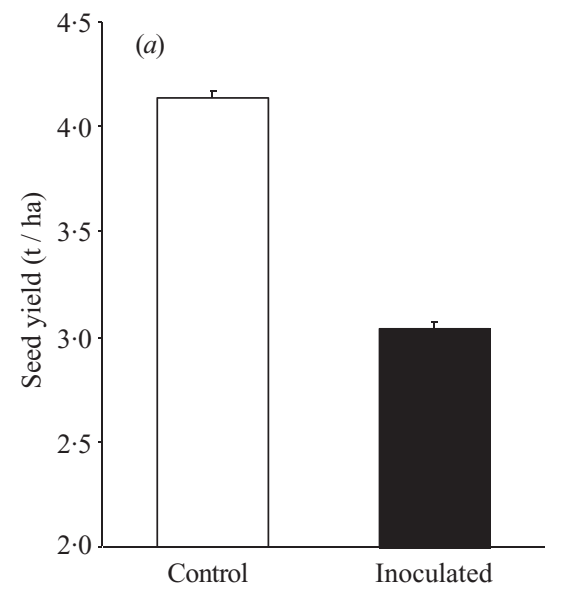

a significant difference at $P<0.001 \quad$ LSD $=0 \cdot 49$, 11 D.F.). Conversely, BWYV-infection gave a significant increase in the glucosinolate concentration, from $16 \cdot 12 \mu \mathrm{mol} / \mathrm{g}$ in the control plots to $18 \cdot 37$ $\mu \mathrm{mol} / \mathrm{g}$ in the inoculated plots $(P<0 \cdot 001)(\mathrm{LSD}=$ $1 \cdot 01,11$ D.F.) (Figs. $4 a$ and $4 b$ ).

\section{Effect of inoculation pressure on yield}

The mean BWYV incidence in March was $13.38 \%$ for the control plots, $44.75 \%$ for the $50 \%$ inoculated plots and $75.25 \%$ for the $100 \%$ inoculated plots. The incidence in the plots for each of the 0,50 and $100 \%$ inoculations varied about the mean, providing a range of values between $2-35 \%, 33-63 \%$ and

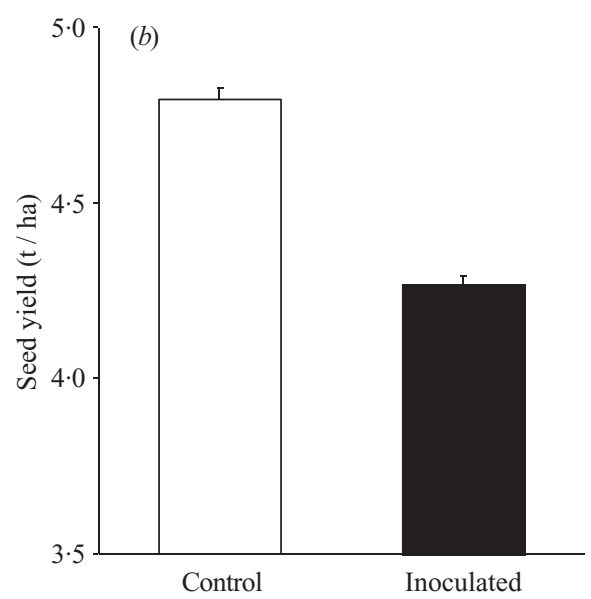

Fig. 3. The effect of BWYV on the final seed yield of oilseed rape in (a) 1994 and (b) 1995. Vertical bars represent the standard error of the means with 11 D.F. 

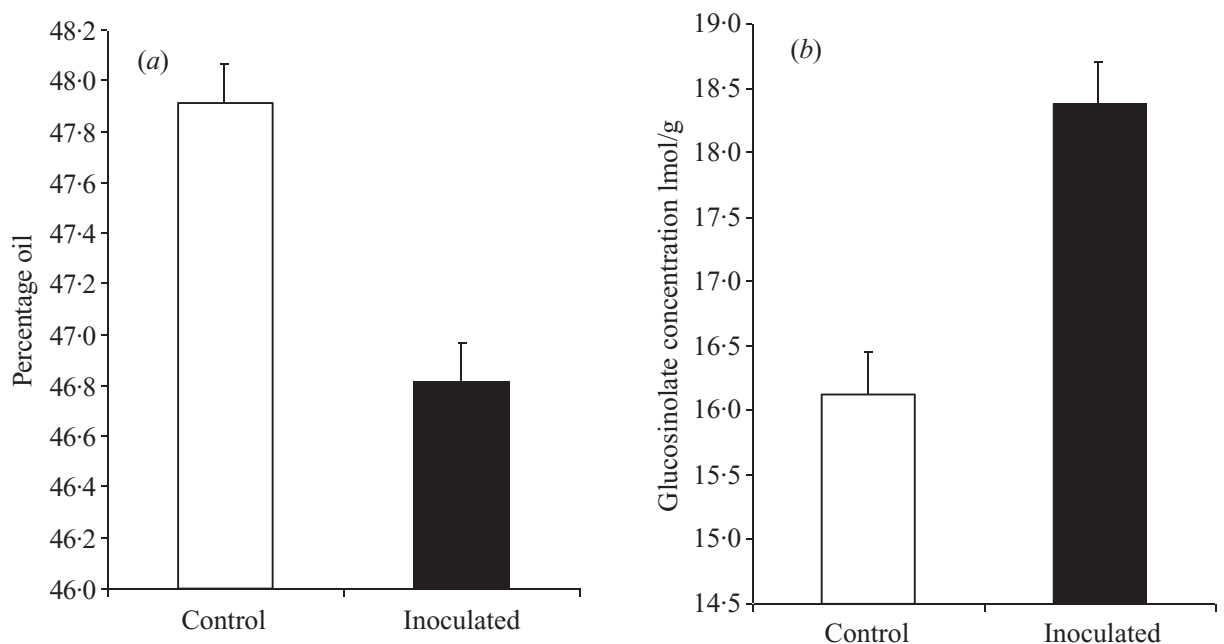

Fig. 4. The effect of BWYV on the $(a)$ percentage oil and $(b)$ glucosinolate concentration in oilseed rape seeds in 1995. Vertical bars represent the standard error of the means with 11 D.F.

$61-85 \%$ respectively. The final combine-harvested seed yields were inversely proportional to the area of the plot that was inoculated with BWYV. Final seed yields of $4 \cdot 51,4 \cdot 41$ and $4 \cdot 11 \mathrm{t} /$ ha were obtained for the 0,50 and $100 \%$ inoculated plots respectively, with a strong effect of treatment on seed yield $(P<0.001$, $\mathrm{LSD}=0 \cdot 17,18$ D.F.). A strong linear effect could be seen which was significant at $P<0 \cdot 001$. $T$-tests were carried out to compare virus incidence, although these were not significant as there was a strong block effect. A regression was fitted with the percentage infection per plot against the seed yield $(\mathrm{t} / \mathrm{ha})$ per plot to form the equation $y=-0 \cdot 0085 x+4 \cdot 7145$, where $y=$ yield and $x=$ incidence of infection with BWYV, which was significant at $P<0.05(r=-0.492)$. There was a general decrease in the seed yield with increasing infection levels, with a wide scatter due to the block effect.

\section{DISCUSSION}

A high incidence of BWYV was achieved in the inoculated plots in both seasons, whereas the uninoculated plots remained relatively virus-free throughout the growing season. The effects of BWYV on growth of oilseed rape were not consistent between years, possibly because of varietal effect, also because environmental conditions varied.

Numbers of pods and seeds per pod and TSW

BWYV infection resulted in lower pod weight and a lower number of seeds per pod. This effect on seed number may have been due to the presence of BWYV in the phloem. Assimilate supply is an important factor in determining pod formation and seed set (Mendham et al. 1981). There has been little research into the physiological effects of BWYV, however studies on barley yellow dwarf luteovirus have shown that the disruption of the phloem leads to reduced translocation and therefore carbohydrate accumulation, with an increase in dry weight and respiration, but with a reduction in chlorophyll content and photosynthesis (Jensen \& D'Arcy 1995). Sugar content has been found to increase in the leaves of BYDV-infected winter wheat, but decline in the grain. Grain-fill in wheat seems to be determined by the photosynthetic production of the flag leaf, head and awns (Stoy 1963), which would be reduced in an infected plant. If this pattern is similar for oilseed rape, it would be expected that reduced photosynthesis and translocation of photosynthates in infected leaves would decrease the assimilate availability which would affect seed set.

The TSW was increased in BWYV-infected plants. The growth rate of seeds is determined either by assimilate availability during seed filling and the number of competing seeds, or by the maximum growth rate of the seeds (Mendham et al. 1981). The increased TSW is likely to be as a direct consequence of having fewer seeds per pod, with less competition for available assimilates. The lower seed number per pod was the main contributing factor in the lower seed yields of the infected plots.

\section{$B W Y V$ in pod components}

The results indicated that virus particles can occasionally reach the embryo, which suggests that seed transmission of BWYV should not be discounted, and requires further investigation. For a virus to be truly seed transmitted it must infect the embryonic tissue, such as lettuce mosaic virus (LMV). LMV has been 
found throughout the ovular tissues, but not in the embryo sac (Hunter \& Bowyer 1993). For one sample which was tested, BWYV was detected in the outer seed coat, but not the inner coat, supporting the idea that there may be some point in the seed coat at which virus movement generally stops, however as only one sample was tested this result is preliminary. The results in this experiment were in agreement with those of Maisonneuve et al. (1995) who found BWYV in pod walls and in immature seeds. They did not, however, separate the seeds into the seed coat and embryo, and the positive readings for the embryos that they obtained may have been due to virus in the seed coat. Seed transmission, even at very low incidence, could have a marked effect on the epidemiology of BWYV. Final incidence of LMV in lettuce crops is dependent on the initial rate of seed transmission and on both the subsequent activity and population density of aphid vectors (Zink et al. 1956).

\section{Final seed yields}

Compared to the controls, the final seed yields were lower in the infected plots by $26 \%$ in 1994 and $11 \%$ in 1995. These losses occurred when infection was high, although the second 1995 trial showed that the yield was inversely proportional to virus incidence. With the cost of spraying insecticides at $c$. £10-20 per hectare all of the yield losses shown in the field trials would have made spraying economically viable.

The loss was shown to be enhanced in 1995 by a decrease in the oil content in the infected seeds from 47.9 to $46.8 \%$ and an increase in the glucosinolate level of the infected seeds from $16 \cdot 12$ to $18 \cdot 37 \mu \mathrm{mol} / \mathrm{g}$. High amounts of glucosinolate are of concern when the meal is used for animal feed, and current breeding aims to decrease the glucosinolates. Glucosinolate in the seed is also important if the next crop is to be grown from farm-saved seed. In order for the crop to qualify for area payment, the quantity of glucosinolate in the farm-saved seed must be $<18.0 \mu \mathrm{mol} / \mathrm{g}$ (Anon 1995). Infection with BWYV can increase the quantity of glucosinolate to above this figure, which could potentially prevent growers from using farm-saved seed for their next crop. Higher glucosinolate values may be the result of bigger seeds; both Milford \& Evans (1991) and Merrien (1989) have reported a positive correlation between seed weight and glucosinolate content.

These studies have shown that BWYV can cause economic losses in oilseed rape and therefore control measures may in some years be warranted. Advice on control must be based on a forecasting scheme, since unnecessary or prophylactic spraying could lead to an increase in the numbers of resistant aphids, which could adversely affect their control in other crops in oilseed rape growing areas, such as sugar beet. Sugar beet is a host of a closely related virus, beet mild yellowing virus (BMYV), also transmitted by $M$. persicae. BWYV does not infect sugar beet in Europe, and may even represent an isolate of turnip yellows virus (Graichen \& Rabenstein 1996), however, both BWYV and BMYV share a number of common weed hosts. An increase in aphids that contain both strains of virus may increase the incidence of yellowing in sugar beet. An integrated approach to disease control is needed, which should also include the use of resistant varieties in conjunction with chemical control.

We thank ADAS Laboratory services for oil and glucosinolate analysis, Zeneca trials officers for help with harvesting and IACR-Rothamsted and Germains Seeds for threshing and grading equipment respectively. Thanks are also due to G. Milford and A. Todd for advice. This work was funded by Zeneca Crop Protection.

\section{REFERENCES}

ANON (1995). Oilseeds Variety Handbook, NIAB Recommended and Descriptive Lists of Oilseeds Crops 1995. Cambridge: The National Institute of Agricultural Botany.

Clark, M. F. \& Adams, A. N. (1977). Characteristics of the microplate method of enzyme-linked immunosorbent assay for the detection of plant viruses. Journal of General Virology 34, 475-483.

D'Arcy, C. J., Torrance, L. \& Martin, R. R. (1989). Discrimination among luteoviruses and their strains by monoclonal antibodies and identification of common epitopes. Phytopathology 79, 869-873.

Graichen, K. \& Rabenstein, F. (1996). European isolates of beet western yellows virus (BWYV) from oilseed rape (Brassica napus $\mathrm{L}$ ssp. napus) are non-pathogenic on sugar beet (Beta vulgaris $\mathrm{L}$ var. altissima) but represent isolates of turnip yellows virus (TuYV). Zeitschrift für Pflanzenkrankheiten und Pflanzenschutz 103, 233-245.
Hardwick, N. V., Davies, J. M. L. \& Wright, D. M. (1994). The incidence of three virus diseases of winter oilseed rape in England and Wales in the 1991/92 and 1992/93 growing seasons. Plant Pathology 43, 1045-1049.

Hill, S. A., Lane, A. \& Hardwick, N. V. (1989). The incidence and importance of beet western yellows virus in oilseed rape. Aspects of Applied Biology 23, 311-318.

Hunter, D. G. \& Bowyer, J. W. (1993). Cytopathology of lettuce mosaic virus-infected lettuce seeds and seedlings. Journal of Phytopathology 137, 61-72.

Jensen, S. G. \& D'Arcy, C. J. (1995). Effects of barley yellow dwarf virus. In Barley Yellow Dwarf. 40 Years of Progress (Eds C. J. D’Arcy \& P. A. Burnett), pp. 55-74. St. Paul, Minnesota: APS Press.

Lane, A. \& Walters, K. F. A. (1993). Recent incidence and cost effective control of pests of oilseed rape in England and Wales. Bulletin OILB/SROP 16, 185-192.

Maisonneuve, C., Deverchère, J. \& Pilorge, E. (1995). 
Virus diseases on rapeseed: distribution in plants, effects on yield, and cartography in France. In Proceedings of the Ninth International Rapeseed Congress-Rapeseed Today and Tomorrow, pp. 661-663. Dorchester: Henry Ling Limited.

Mendham, N. J., Shipway, P. A. \& Scott, R. K. (1981) The effects of delayed sowing and weather on growth, development and yield of winter oilseed rape (Brassica napus L.). Journal of Agricultural Science, Cambridge 84, 487-502.

Merrien, A. (1989). Double low oilseed rape in France: factors affecting glucosinolate levels. Aspects of Applied Biology 23, Production and Protection of Oilseed Rape and other Brassica Crops, 109-116.

Milford, G. F. J. \& Evans, E. J. (1991). Factors causing variation in glucosinolates in oilseed rape. Outlook on Agriculture 20, 31-37.

Payne, R. W., Lane, P. W., Ainsley, A. E., Bicknell, K. E., Digby, P. G. N., Harding S. A., Leech, P. K., Simpson, H. R., Todd, A. D., Verrier, P. J., White, R. P., Gower, J. C., TunNicliffe Wilson, G. \& Paterson, L. J. (1987). Genstat 5 Reference Manual. Oxford: Oxford University Press.

Schnug, E. \& Haneklaus, S. (1988). Theoretical principles for the indirect determination of the total glucosinolate content in rapeseed and meal quantifying the sulphur concentration via X-Ray Fluorescence (X-RF method). Journal of the Science of Food and Agriculture 45, 243-254.
SCHRÖDER, M. (1994). Investigations on the susceptibility of oilseed rape to different virus diseases. Zeitschrift für Pflanzenkrankheiten und Pflanzenschutz 101, 576-589.

Smith, H. G. \& Hinckes, J. A. (1984). Luteovirus interactions between oilseed rape and sugar beet. In Proceedings of the 1984 British Crop Protection Conference-Pests and Diseases, 831-835.

Smith, H. G. \& Hinckes, J. A. (1985). Studies on beet western yellows virus in oilseed rape (Brassica napus ssp. oleifera) and sugar beet (Beta vulgaris). Annals of Applied Biology 107, 473-484.

Sylvester-Bradley, R. \& Makepeace, R. J. (1984). A code for stages of development in oilseed rape (Brassica napus L.). Aspects of Applied Biology 6, Agronomy, Physiology, Plant Breeding and Crop Protection of Oilseed Rape, 399-419.

Stоy, V. (1963). The translocation of $\mathrm{C}^{14}$-labeled photosynthetic products from the leaf to the ear in wheat. Physiological Plant Pathology 16, 851-866.

Tomassetti, M., Campanella, L., Aureli, T. \& Sammartino, M. P. (1991). TG and NMR analysis of commercial plant oil seeds. Thermochimica Acta 190, 131-141.

Zink, F. W., Grogan, R. G. \& Welch, J. E. (1956). The effect of the percentage of seed transmission upon subsequent spread of lettuce mosaic virus. Phytopathology 46, 662-664. 